Document downloaded from:

http://hdl.handle.net/10251/63891

This paper must be cited as:

Moset, V.; Cambra López, M.; Estellés, F.; Torres Salvador, AG.; Cerisuelo, A. (2012). Evolution of chemical composition and gas emissions from aged pig slurry during outdoor storage with and without prior solid separation. Biosystems Engineering. 111(1):2-10. doi:10.1016/j.biosystemseng.2011.10.001.

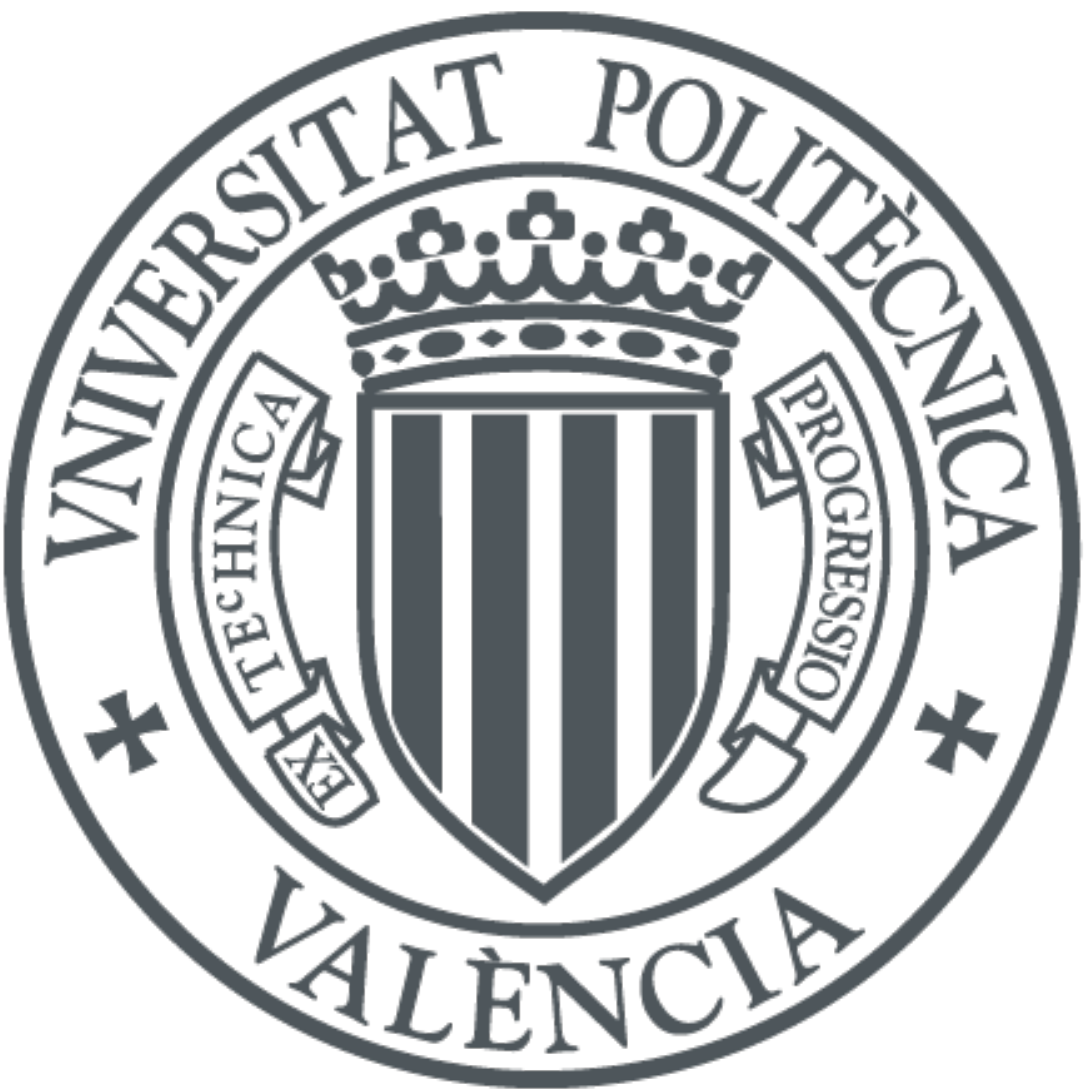

The final publication is available at

http://dx.doi.org/10.1016/j.biosystemseng.2011.10.001

Copyright Elsevier

Additional Information 


\title{
Evolution of chemical composition and gas emission from aged pig slurry during outdoor storage with and without prior solid separation
}

\author{
V. Moset ${ }^{* a b}$, M. Cambra-López ${ }^{\text {b }}$, F. Estellés ${ }^{\mathrm{b}}$, A.G. Torres ${ }^{\mathrm{b}}$, A. Cerisuelo $^{\mathrm{a}}$ \\ a Animal and Technology Research Center (CITA-IVIA). Pol. Esperanza 100, 12400. \\ Segorbe, Castellón, Spain. \\ ${ }^{\mathrm{b}}$ Institute of Animal Science and Technology. Universitat Politècnica de València (UPV), \\ Cno. de Vera 14, 46022. Valencia, Spain.
}

Abstract. Chemical composition and gas emissions from two types of pig slurry were evaluated: the liquid fraction of mechanical solid-liquid separated slurry (SS), and raw slurry (RS). The slurry was obtained at the end of a pig fattening period and stored in 1001 vessels for 15 weeks simulating outdoor storage conditions. During this period, representative samples were taken and analysed for chemical composition. Methane, carbon dioxide, ammonia, water vapour and nitrous oxide emissions were recorded. The results showed a high biological degradation during the first five weeks of outdoor storage in SS and RS slurries, as a result of an increase in the dissolved chemical oxygen demand, volatile fatty acids and carbon dioxide emission observed in this period. However, methanogenic activity was not evident until week 6 of storage in both slurries, confirmed by the volatile fatty acids accumulation and the negligible methane emissions during the first five weeks of storage. The results showed that differences in the initial slurry organic matter content, influenced by solid separation process, affects the evolution pattern of the

\footnotetext{
* Corresponding author: Tel.: +34 9647121 15; Fax: +34 9647102 18; E-mail address: moset_ver@gva.es
} (V. Moset) 
21 organic matter degradation and that the storage time can considerably affect the biodegradability of organic matter in pig slurry.

23 Keywords: chemical composition, gas emission, aged pig slurry, solid-separation, storage

24 conditions.

25 Nomenclature

ADF Acid detergent fibre, $\mathrm{g} \mathrm{kg}^{-1}[\mathrm{FM}]$

ADL Acid detergent lignin, $\mathrm{g} \mathrm{kg}^{-1}[\mathrm{FM}]$

$\mathrm{C}_{\mathrm{in}} \quad$ Gas concentration in the input, $\mathrm{mg} \mathrm{m}^{-3}$

$\mathrm{COD}_{\mathrm{d}} \quad$ Dissolved chemical oxygen demand, $\mathrm{g}^{-1}$

$\mathrm{C}_{\text {out }}$ Gas concentration in the output, $\mathrm{mg} \mathrm{m}^{-3}$

E Gas emission rates, $\mathrm{mg} \mathrm{h}^{-1}$

F $\quad$ Airflow rate $\mathrm{m}^{3} \mathrm{~h}^{-1}$

FM Fresh matter

NDF Neutral detergent fibre, $\mathrm{g} \mathrm{kg}^{-1}[\mathrm{FM}]$

OM Organic matter

RS Raw slurry

SS Separated slurry after solid separation

$\mathrm{TKN}_{\mathrm{d}} \quad$ Dissolved Kjeldhal nitrogen, $\mathrm{g} \mathrm{kg}^{-1}[\mathrm{FM}]$

$\mathrm{TKN}_{\mathrm{t}}$ Total Kjeldhal nitrogen, $\mathrm{g} \mathrm{kg}^{-1}$ [FM]

TS Total solids, $\mathrm{g} \mathrm{kg}^{-1}[\mathrm{FM}]$

VFA Volatile fatty acids, $\mathrm{g}^{-1}$

VS Volatile solids, $\mathrm{g} \mathrm{kg}^{-1}$ [FM] 
The anaerobic degradation of organic matter (OM) takes place during the storage of animal slurries like in any anoxic and rich in OM environment such as rice paddies, the rumen or the hind gut of monogastrics. This is a complex process in which different groups of bacteria interact to convert $\mathrm{OM}$ into carbon dioxide $\left(\mathrm{CO}_{2}\right)$ and methane $\left(\mathrm{CH}_{4}\right)$. Primarily, hydrolytic enzymes from the fermentative bacteria convert complex polymeric biomass (polysaccharides, proteins, lipids, etc.) into their respective monomeric constituents (sugars, amino acids, fatty acids, etc.). The acidogenic fermentative bacteria transform these monomers into $\mathrm{H}_{2}, \mathrm{CO}_{2}$ and volatile fatty acids (VFA). The VFA are then converted by the acetogenic bacteria into acetic acid, which is the main product utilised by the methanogenic bacteria, the last group of bacteria which is established in the anaerobic degradation process (Angelidaki et al. 1999).

During animal slurry storage, all of these bacterial groups coexist in equilibrium with other groups responsible for processes such as aerobic degradation of OM (Moller et al., 2004), nitrogen nitrification, denitrification and urea mineralisation (Cortus et al., 2008). This high bacterial activity results in the emission of gases related with climate change and detrimental environmental effects such as ammonia $\left(\mathrm{NH}_{3}\right)$ and greenhouse gases $\left(\mathrm{CO}_{2}, \mathrm{CH}_{4}\right.$ and nitrous oxide, $\mathrm{N}_{2} \mathrm{O}$ ). Besides gas emissions, bacterial fermentation processes can also lead to a reduction not only in the fertiliser value of manure due to nitrogen losses (Muck and Steenhuis, 1982), but also as energy value to produce biogas due to fermentable OM losses (Moller et al., 2004).

Storage conditions, slurry composition and age are key influencing factors in the performance of these bacteria. Storage conditions affect the anaerobiosis degree of the 
slurry, limiting the establishment of anaerobic versus aerobic bacteria. Furthermore, slurry composition affects the establishment of bacteria in the slurry not only because some components, as nitrogen and biodegradable carbon are sources of energy for them, but also because, as stated Fangueiro et al. (2008), the higher contents of OM, especially solids with low density such as fibres, could facilitate more anaerobic conditions and thus a better development and establishment of anaerobic bacteria. Therefore, treatments such as solidliquid separation where high contents of fibres are separated from liquid to solid phases could have a relevant effect on anaerobic conditions and thus on $\mathrm{CH}_{4}$ emissions.

Slurry composition depends not only on well known factors such as diet or slurry management (Cahn et al., 1997, Béline et al., 1999, Panetta el al., 2006) but also on its age. The OM in slurry is formed by degradable and non-degradable volatile solids, during storage, the degradation of the most degradable OM by bacterial activity causes an increases in fibrous content in the slurry (Sommer et al. 2004), since this fraction is unaffected by bacterial activity. In addition, during the degradation of slurry there is an accumulation of compounds as metabolic products of the fermentative bacteria (such as VFA) and mineralisation products of nitrogen as $\mathrm{NH}_{3}$ and $\mathrm{N}_{2} \mathrm{O}$ (Béline et al., 1998). Consequently, gas emissions derived from aged slurry are expected to differ over time from these obtained from fresh slurry, thereby affecting its subsequent management.

Monitoring gas emissions and slurry composition during storage might help elucidate the variation of bacterial activity with time. Methane emission is produced only by anaerobic bacteria and $\mathrm{NH}_{3}$ is produced in the mineralisation of organic nitrogen. However, $\mathrm{CO}_{2}$ is produced by anaerobic and aerobic bacteria and is also related with urea mineralisation. 
There are several works reported in the literature in which fresh slurry is monitored for gas emission and composition over time at different temperatures (Béline et al., 1997, Moller et al., 2004; Sommer et al., 2007) identifying temperature and slurry composition as the most influencing factors affecting gas emission. However, gas emissions and slurry composition in aged slurry stored over long periods in warm temperature conditions $\left(>20^{\circ} \mathrm{C}\right)$ have been studied to a lesser extent and this could provide useful information to develop best management practices to reduce environmental impact caused during aged slurry storage. This information is particularly relevant in Mediterranean counties, such as Spain, where the management of pig slurry consists of a pre-storage below slatted floor during the fattening period (3-4 months) and a further outdoor storage occurs until the slurry is applied to agricultural land. In this context, mechanical solid separation treatment techniques are often applied to reduce the capacity of the outdoor storage lagoons and facilitate slurry transport and field application.

The aim of this study was to monitor gas emissions $\left(\mathrm{CH}_{4}, \mathrm{CO}_{2}, \mathrm{~N}_{2} \mathrm{O}, \mathrm{NH}_{3}\right.$ and $\left.\mathrm{H}_{2} \mathrm{O}\right)$ and the chemical composition of two types of aged fattening pig slurry during 15 consecutive weeks under summer conditions, and to study the effect of initial slurry chemical composition on these parameters by applying the mechanical solid separation process.

\section{Material and methods}

\subsection{Experimental setup}

Pig slurry from a complete fattening period (19 weeks) carried out with 128 female pigs (initial weight $20.85 \pm 2.80 \mathrm{~kg}$ ), was obtained from the Animal and Technology Research Centre (CITA) in Segorbe, Castellón, Spain. The animals were fed a diet containing, on average, $2,425 \mathrm{kcal}$ net energy $\mathrm{kg}^{-1}, 15.1 \%$ crude protein, $5.8 \%$ crude fat and $3.9 \%$ crude 
fibre. Animals were housed in whole-slatted pens. At the end of the fattening period, the slurry under the pit was mixed in order to avoid stratification and a representative sample $(2,000$ 1) was taken. Approximately half of the total amount of collected slurry was immediately subjected to a mechanical solid separation process via a mechanical screen separator, with a screen pore diameter of $0.5 \mathrm{~mm}$, commonly used in commercial farms. This slurry was designated separated slurry (SS). The rest was not modified and remained as raw slurry (RS).

For each treatment three 1001 polyethylene vessels were filled with slurry until they reached $80 \%$ of their total capacity. A headspace of $130 \mathrm{~mm}$ was left between the slurry surface $\left(0.104 \mathrm{~m}^{2}\right)$ and the top of each vessel. During 15 consecutive weeks in summer, vessels were stored in a roofed space. Slurry and ambient temperature were continuously registered using dataloggers $(\mathrm{HOBO} \circledast U$ U12-013, Onset Computer Corporation, MA, USA).

\subsection{Chemical analyses}

At the beginning of the experiment, and fortnightly, a representative sample of the slurry from each vessel was taken. The samples were collected using a device for layered liquids sampling (Eijkelkamp®, Eijkelkamp Agrisearch Equipment BV, Germany) that allows sampling the complete vertical profile of the slurry without agitation. After collection, the samples were homogenised and the $\mathrm{pH}$ was measured with a $\mathrm{pH}$ meter (Crison Basic 20+, Crison, Barcelona, Spain). After $\mathrm{pH}$ measurements, samples were frozen at $-30^{\circ} \mathrm{C}$.

Total solids (TS), volatile solids (VS), total and dissolved Kjeldhal nitrogen $\left(\mathrm{TKN}_{\mathrm{t}}\right.$ and $\left.\mathrm{TKN}_{\mathrm{d}}\right)$, and dissolved chemical oxygen demand $\left(\mathrm{COD}_{\mathrm{d}}\right)$ were determined according to APHA (2005). Volatile fatty acids concentration was determined by gas chromatography 
117 following the method described by Jouany (1982) with the addition of an internal standard

118 (4-metil valeric). Neutral detergent fibre (NDF), acid detergent fibre (ADF) and acid

119 detergent lignin (ADL) were determined according to the Van Soest procedure (Van Soest,

120 1991). The nitrogen and fibre content were only determined in weeks 0,9 and 15.

$121 \quad$ 2.3.Gas emissions

122 From the filling of the vessels and during the 15 weeks of storage, gas emissions were

123 measured treating the vessels as dynamic chambers. The gas measurements were performed

124 weekly (3 days per week). On each measuring day, the emissions from two vessels, one

125 from SS treatment and one from RS treatment, were registered during $24 \mathrm{~h}$. During week

12611 of the study, no gas measurements were conducted due to equipment malfunctioning.

127 The dynamic chambers were set up by sealing the vessels containing the slurry with

128 hermetic lids. Three holes were left in the lid for air inlet by depression (inlet holes). The

129 air was sucked from each headspace by a pump (38 $1 \mathrm{~min}^{-1}$ and $7.5 \mathrm{kPa}$ (outlet), Ilmivac,

130 Ilmenau, Germany). Inlet and outlet holes were on opposite sides of the lid to promote air

131 mixing in the headspace. When vessels were not being measured for gas emissions, they

132 remained open to simulate natural conditions in outdoor storage.

133 Inlet and outlet concentrations of $\mathrm{CH}_{4}, \mathrm{CO}_{2}, \mathrm{~N}_{2} \mathrm{O}$, water vapour $\left(\mathrm{H}_{2} \mathrm{O}\right)$ and $\mathrm{NH}_{3}$ were 134 analyzed every two hours using a photoacoustic gas monitor (INNOVA1412, Air Tech 135 Instruments, Ballerup, Denmark).

136 The airflow rate was measured daily in the outlet using a flow meter (Aalborg instruments

137 and Controls INC., NY, USA) and modified if necessary to keep concentrations in the

138 measuring range of the equipment; therefore, airflows in this study ranged from $0.30 \mathrm{~m}^{3} \mathrm{~h}^{-1}$

139 at the beginning and $1.03 \mathrm{~m}^{3} \mathrm{~h}^{-1}$ at the end of the measuring period. 
141 Gas emission rates $\left(\mathrm{E}, \mathrm{mg} \mathrm{h}^{-1}\right)$ were calculated by multiplying the airflow rate times the 142 difference between the gas concentrations in the output and input holes of each vessel for 143 each measured gas, using Eq. (1).

$$
\mathrm{E}=\mathrm{F} x\left(\mathrm{C}_{\text {out }}-\mathrm{C}_{\text {in }}\right)
$$

145 where: $\mathrm{F}$ is the airflow rate through the vessel $\left(\mathrm{m}^{3} \mathrm{~h}^{-1}\right), \mathrm{C}_{\mathrm{out}}$ is the gas concentration in the 146 output $\left(\mathrm{mg} \mathrm{m}^{-3}\right)$, and $\mathrm{C}_{\text {in }}$ is the gas concentration in the input $\left(\mathrm{mg} \mathrm{m}^{-3}\right)$.

147 The evolution of slurry chemical composition and gas emission at different moments over 148 the storage period was analysed using a repeated measures analysis (PROC MIXED) of $149 \mathrm{SAS}^{\circledR}$ (2001). The relationship between chemical parameters and $\mathrm{pH}$ was studied using a 150 correlation analysis (PROC CORR) of SAS ${ }^{\circledR}$.

\section{3. Results}

152 Fig. 1 shows the evolution of the hourly environmental and slurry temperature pooled by 153 treatment. Environmental temperature showed a clear diurnal fluctuation at hourly 154 intervals. However the environmental temperature during the experiment was similar 155 among weeks, except for the final week (from week 13 to 15) in which a decrease of the 156 environmental temperature was observed. The average environmental temperature recorded $15724.9 \pm 2.90{ }^{\circ} \mathrm{C}$, ranged from $15.3{ }^{\circ} \mathrm{C}$ to $30.32{ }^{\circ} \mathrm{C}$. As regards the slurry temperature, these 158 diurnal fluctuations were less marked than for environmental temperature, being the 159 average slurry temperature equal to $23.9 \pm 1.85^{\circ} \mathrm{C}$, ranged from $18.9^{\circ} \mathrm{C}$ and $26.2^{\circ} \mathrm{C}$.

\section{$160 \quad$ 3.1.Effect of storage time on slurry chemical composition}

161 Fig. 2 shows the evolution of TS and VS in SS and RS over the 15-week storage period. 162 Raw slurry showed a higher content of TS $(\mathrm{p}<0.05)$ and VS $(\mathrm{p}<0.01)$ than SS slurry at the 
163 beginning and throughout the storage period. At the beginning of the storage period (week

164 1), the concentration of TS and VS were $31.3 \pm 1.93 \mathrm{~g} \mathrm{~kg}^{-1}$ in SS and $37.1 \pm 1.93 \mathrm{~g} \mathrm{~kg}^{-1}$ in RS,

165 for TS; and $27.1 \pm 1.68 \mathrm{~g} \mathrm{~kg}^{-1}$ in SS and $35.1 \pm 1.68 \mathrm{~g} \mathrm{~kg}^{-1}$ in RS, for VS. At the end of the

166 storage period (week 15), the differences in TS and VS between treatments increased

$167 \quad(\mathrm{p}<0.001)$ compared with those observed at the beginning of the storage period $(\mathrm{p}<0.05)$.

168 Regarding TS and VS evolution over the 15-week period, both TS and VS concentration

169 showed a marked decrease during the first three weeks of storage, being this especially

170 relevant for VS. From this point onwards, TS and VS concentration remained constant or

171 slightly increased, showing an increment in both slurries by the end of the study.

172 Table 1 shows the chemical composition of manure in terms of TKN and fibrous

173 components on weeks 0,9 and 15 of the study. As for TS and VS, nitrogenous compounds

$174 \quad\left(\mathrm{TKN}_{\mathrm{t}}\right.$ and $\mathrm{TKN}_{\mathrm{d}}$ values) in RS were higher than those obtained for SS throughout the

175 storage period. However, the differences between treatments were only statistically

176 significant at the end of the storage period (week 15) and only in the case of $\mathrm{TKN}_{\mathrm{t}}$.

177 Concerning $\mathrm{TKN}_{\mathrm{t}}$ and $\mathrm{TKN}_{\mathrm{d}}$ evolution, both of them showed a slight decrease over the 178 storage period.

179 Regarding fibre content, NDF and ADF were significantly higher in RS compared to SS 180 slurry on weeks $9(\mathrm{p}<0.05)$ and 15 (p <0.001) of the study. On week 15, the ADL content 181 was also significantly higher $(\mathrm{p}<0.001)$ in RS than in SS. Over the storage period, NDF, $182 \mathrm{ADF}$ and ADL concentrations decreased from week 0 to week 9 and increased from week 9 183 to 15 of the storage period in both treatments, this increase was more pronounced in RS 184 compared to SS. 
185 Fig. 3 shows the evolution of the $\mathrm{COD}_{\mathrm{d}}$ in the $\mathrm{SS}$ and RS slurries. During the first three 186 weeks of storage, the $\mathrm{COD}_{\mathrm{d}}$ content increased in RS being the $\mathrm{COD}_{\mathrm{d}}$ levels in week 3 and 5

187 significantly higher in $\mathrm{RS}$ than in $\mathrm{SS}(\mathrm{p}<0.05)$. Thereafter $\mathrm{COD}_{\mathrm{d}}$ decreased reaching the 188 minimum values in week 13 of storage. After week 13, there was a similar increase in $189 \mathrm{COD}_{\mathrm{d}}$ content in both slurries, RS and SS.

190 Fig. 4 shows the total VFA content and the individual VFA (acetic, propionic, butyric and 191 isobutyric acids) concentration during the storage period. As for the $\mathrm{COD}_{\mathrm{d}}$, total VFA 192 content in the slurry increased within the first three weeks of the storage period in RS and 193 until the fifth week in SS slurry. An increase in total VFA was observed on week 11 for $<0.05)$. Acetate evolution showed a similar trend than the total VFA, also peaking in week 11 in RS. During the first 11 weeks of storage, acetate comprised approximately $50 \%$ of the

197 total VFA in both slurries, declining thereafter until 38\% in RS and 32\% in SS at the end of 198 the storage period.

199 There were no statistically significant differences between treatments in the evolution of 200 propionate until the end of the experimental period (week 15). Propionate followed the 201 same trend as total VFA during the first nine weeks in both slurries, thereafter its 202 concentration in both slurries increased, contrary to total VFA evolution, being higher in 203 RS compared to SS slurry during almost the whole storage period. At the end of the storage 204 period propionate comprised $57 \%$ in RS and $62 \%$ in SS of the total VFA. Concerning 205 butyrate, its concentration increased during the first three weeks of storage and decreased 206 thereafter reaching negligible levels. The values for butyrate obtained for RS were higher 207 than those obtained for SS during almost all the storage period. However, the concentration 
208 of isobutyrate increased during the first 9 weeks (SS) and 11 weeks (RS) in the storage 209 period, and decreased thereafter.

210 Fig. 5 shows the evolution of the $\mathrm{pH}$ of both slurries. Contrary to total VFA, the pH of both 211 slurries decreased during the first three weeks and increased thereafter until week 15 . There 212 were differences between treatments in weeks 9 and 11 of the study, being the pH in SS 213 slurry significantly higher than that of RS ( $p<0.05)$ at these moments.

214 When $\mathrm{pH}$ was correlated with VFA it was obtained that VFA content explained $80 \%$ of the 215 variation in $\mathrm{pH}\left(\mathrm{R}^{2}=0.80, \mathrm{p}<0.001\right)$ and the relationship between these two variables, in the 216 range of the $\mathrm{pH}$ variation in this experiment, was linear and negative, indicating that the 217 higher levels of VFA the lower $\mathrm{pH}$ values.

\subsection{Effect of storage time on gas emissions}

219 The emissions of $\mathrm{H}_{2} \mathrm{O}$ and $\mathrm{N}_{2} \mathrm{O}$ over the storage period were similar and followed a similar 220 pattern among them (data not shown). The minimum emission rates of $\mathrm{H}_{2} \mathrm{O}$ and $\mathrm{N}_{2} \mathrm{O}$ were 221 recorded at the beginning of the storage period and the maximum levels were observed in 222 week 10 for both gases $\left(\mathrm{H}_{2} \mathrm{O}: \mathrm{RS}=86.41 \mathrm{~g} \mathrm{~h}^{-1} \mathrm{~m}^{-2}\right.$ and $\mathrm{SS}=81.46 \mathrm{~g} \mathrm{~h}^{-1} \mathrm{~m}^{-2}$ and $\mathrm{N}_{2} \mathrm{O}: \mathrm{RS}=$ $2231.98 \mathrm{mg} \mathrm{h}^{-1} \mathrm{~m}^{-2}$ and $\mathrm{SS}=1.59 \mathrm{mg} \mathrm{h}^{-1} \mathrm{~m}^{-2}$ ). Only during week 3 , were there statistical 224 significant differences between treatments $(\mathrm{p}<0.05)$, being $\mathrm{N}_{2} \mathrm{O}$ and $\mathrm{H}_{2} \mathrm{O}$ emissions higher 225 in RS than in SS slurry $\left(\mathrm{H}_{2} \mathrm{O}: \mathrm{RS}=49.58 \mathrm{~g} \mathrm{~h}^{-1} \mathrm{~m}^{-2}\right.$ and $\mathrm{SS}=32.64 \mathrm{~g} \mathrm{~h}^{-1} \mathrm{~m}^{-2}$ and $\mathrm{N}_{2} \mathrm{O}: \mathrm{RS}$ $226=1.64 \mathrm{mg} \mathrm{h}^{-1} \mathrm{~m}^{-2}$ and $\mathrm{SS}=0.94 \mathrm{mg} \mathrm{h}^{-1} \mathrm{~m}^{-2}$ ).

227 Fig. 6 shows the evolution of the weekly average $\mathrm{CO}_{2}$ and $\mathrm{NH}_{3}$ emissions over the 15 -week 228 storage period. During the first three weeks of storage, there was an increase in $\mathrm{CO}_{2}$ 229 emission in RS being $\mathrm{CO}_{2}$ emission in weeks 2 and 3 higher ( $\left.\mathrm{p}<0.001\right)$ in RS than in SS. 230 The maximum $\mathrm{CO}_{2}$ emission rate was observed in week 10 in both slurries $\left(\mathrm{RS}=11.18 \mathrm{~g} \mathrm{~h}^{-}\right.$ 
$231{ }^{1} \mathrm{~m}^{-2}$ and $\left.\mathrm{SS}=9.92 \mathrm{~g} \mathrm{~h}^{-1} \mathrm{~m}^{-2}\right)$. In week $12, \mathrm{CO}_{2}$ emission was again higher $(\mathrm{p}<0.001)$ in $\mathrm{RS}$ 232 than in SS slurry.

233 Ammonia emission increased with time showing emission rates of $0.2-0.3 \mathrm{~g} \mathrm{~h}^{-1} \mathrm{~m}^{-2}$ at the 234 beginning of the storage period and approximately $0.4 \mathrm{~g} \mathrm{~h}^{-1} \mathrm{~m}^{-2}$ at the end. Differences in $235 \mathrm{NH}_{3}$ emissions between treatments were found in week 3, in which $\mathrm{NH}_{3}$ emission was 236 higher $(\mathrm{p}<0.05)$ in RS than in SS slurry.

237 The evolution of the weekly average $\mathrm{CH}_{4}$ emissions over the 15 -week storage period is 238 shown in Fig. 7. Methane emission was very low during the first six weeks of storage in 239 both treatments, however during this period statistical significant differences $(\mathrm{p}<0.05)$ 240 were observed, being $\mathrm{CH}_{4}$ emission higher in RS than in SS slurry. From week 6 onwards, $241 \mathrm{CH}_{4}$ emission increased in both slurries. The maximum measured $\mathrm{CH}_{4}$ emission was 242 reached before in SS slurry than in RS slurry. Maximum measured $\mathrm{CH}_{4}$ emission was 243 reached in week 10 for SS $\left(3.08 \mathrm{~g} \mathrm{~h}^{-1} \mathrm{~m}^{-2}\right)$ and in week 12 for $\mathrm{RS}\left(4.72 \mathrm{~g} \mathrm{~h}^{-1} \mathrm{~m}^{-2}\right)$.

244 Fractions of $\mathrm{C}-\mathrm{CH}_{4}$ emissions to total carbon emission $\left[\mathrm{C}-\mathrm{CH}_{4} /\left(\mathrm{C}-\mathrm{CO}_{2}+\mathrm{C}-\mathrm{CH}_{4}\right)\right]$ were also 245 calculated. The $\mathrm{C}-\mathrm{CH}_{4}\left(\mathrm{C}-\mathrm{CO}_{2}+\mathrm{C}-\mathrm{CH}_{4}\right)$ ratio during the peak of $\mathrm{CH}_{4}$ production (week 10246 12) increased from 0.12 to 0.50 in $\mathrm{SS}$ and from 0.12 to 0.54 in RS.

\section{4. Discussion}

248 The anaerobic degradation of OM from the initial breakdown of organic polymers to the 249 production of $\mathrm{CH}_{4}$ is a long process that comprises different stages. Our results support the 250 stages defined by Angelidaki et al. (1999), where OM is fermented by the acidogenic and 251 acetogenic bacteria leading first to the formation of intermediate VFA and finally to the 252 production of $\mathrm{CH}_{4}$. 
253 In our study, during the first stages of the storage period (first five weeks), there was a 254 relative transformation of the more degradable OM into soluble OM as shown by the 255 decrease in TS, VS, NDF, ADF and ADL concentrations and the increase in COD $_{d}$, VFA 256 concentration and $\mathrm{CO}_{2}$ emission during this period. Then, $\mathrm{COD}_{\mathrm{d}}$ and VFA concentration 257 decreased coinciding with the increase in the $\mathrm{CH}_{4}$ production in both slurries as the final 258 step of the anaerobic OM degradation.

259 Similar trends been observed in other studies when pig fresh slurry was used. Moller et al. 260 (2004) found a similar increment of total VFA content during the first weeks of storage in 261 pig slurry stored at $20^{\circ} \mathrm{C}$ followed by an increment in $\mathrm{CH}_{4}$ emission and a drop of VFA 262 concentration. However, our results show further differences in the OM degradation 263 process between the solid-separated (SS) and the non-separated (RS) slurries. The $\mathrm{COD}_{\mathrm{d}}$ is 264 usually used as an indicator of the degree of OM degradation, since during the first steps of 265 the degradation process; fermentative bacteria hydrolyse and convert the suspended solids 266 into dissolved solids to obtain a continuous food supply for their growth (Zhu et al. 2000). 267 These dissolved solids (composed of soluble organic compounds) are represented by the $268 \mathrm{COD}_{\mathrm{d}}$ content. The higher $\mathrm{COD}_{\mathrm{d}}$ content observed in RS in week 3 in our results compared 269 with SS, might indicate a higher hydrolytic bacteria activity at the beginning of the storage 270 period in RS compared to SS. These results could be related to the higher OM content of 271 RS compared to SS. In fact, the OM concentration is one of the most relevant parameters in 272 the kinetics of its degradation (Vavilin et al., 1996; Vavilin and Angelidaki, 2004). In 273 addition, as suggested by Fangueiro et al. (2008), the higher OM content in RS slurry, 274 especially the higher fibre content, may have promoted better anaerobic conditions in this 275 slurry and thus enhanced anaerobic bacteria establishment. 
The hypothesis that there is a higher bacterial activity in RS during the first weeks is also supported by the higher $\mathrm{CO}_{2}$ emission at this moment in RS compared with SS slurry. The two main sources of $\mathrm{CO}_{2}$ emission from slurry are the microbial degradation of $\mathrm{OM}$ and the urea mineralisation process by the enzyme urease, which also leads to $\mathrm{NH}_{3}$ volatilization (Cortus et al., 2008). The higher $\mathrm{CO}_{2}$ emission rates observed in RS compared to SS in week 3 could have been related with these two processes. As stated above, this could be explained by a higher hydrolytic, acidogenic and acetogenic activity, as shown by the increase in $\mathrm{COD}_{\mathrm{d}}$ and VFA during $\mathrm{OM}$ degradation during the first three weeks of storage, but also by a higher rate of organic nitrogen mineralisation and denitrification, as shown by a higher $\mathrm{NH}_{3}$ and $\mathrm{N}_{2} \mathrm{O}$ emission in $\mathrm{RS}$ at this time (week 3).

The initial VFA content in both slurries was higher compared to values reported in the literature (Moller et al., 2004) in which fresh slurry was used. However, in this study the maximum VFA, which was reached on weeks $3(\mathrm{RS})$ and $5(\mathrm{SS})$, was lower than that obtained in the works in which fresh slurry was used, probably due to the lower content of biodegradable OM in aged pig slurry as regards to fresh slurry. Concerning the individual VFA, at the beginning of the OM degradation process, acetate was the main VFA produced in both slurries. However, at the end of the storage period, the production of propionate was higher, especially in the RS slurry. Accumulations of propionate in slurry storage have been observed also by other authors such as Moller et al. (2004) and Nozhevnikova et al. (2000). These authors suggested that, in outdoor storage conditions, propionate is accumulated as an intermediate product because it is degraded at a lower rate than butyrate and acetate. 
297 Concerning gas emission, $\mathrm{CO}_{2}$ emissions obtained in this work were in a similar range that 298 those obtained by Dinuccio et al. (2008) for a liquid fraction and untreated pig slurry stored 299 at $25^{\circ} \mathrm{C}\left(5-15 \mathrm{mg} \mathrm{CO} \mathrm{h}^{-1} \mathrm{~m}^{-2}\right)$. However, the $\mathrm{NH}_{3}$ emission obtained by Dinuccio et al. 300 (2008) in the liquid fraction and in the untreated pig slurry at $25^{\circ} \mathrm{C}$ was slightly higher 301 (300-700 $\mathrm{mg} \mathrm{NH}_{3} \mathrm{~h}^{-1} \mathrm{~m}^{-2}$ ) that those obtained in this work, probably because these authors 302 used fresh pig slurry. As stated by Béline et al., (1998) a large part of the nitrogen organic 303 is mineralised during the first two weeks of storage in fresh slurries, therefore low and 304 stable $\mathrm{NH}_{3}$ emissions over time are expected in aged slurries instead of the observed 305 increase in $\mathrm{NH}_{3}$ emissions during the storage period obtained in this study. However, this 306 increase could be related with the increment in the $\mathrm{pH}$ of both slurries because as stated 307 Muck and Steenhuis (1982) and Canh et al. (1998) the $\mathrm{pH}$ of the slurry is one of the most 308 important factors influencing $\mathrm{NH}_{3}$ emission.

$309 \mathrm{~N}_{2} \mathrm{O}$ emission obtained in this work was lower compared than those obtained by Amon et 310 al. (2006) using untreated pig slurry at $10^{\circ} \mathrm{C}$. However, it was similar to that obtained by 311 Dinuccio et al. (2008) at $25^{\circ} \mathrm{C}$. These authors registered negligible $\mathrm{N}_{2} \mathrm{O}$ emission in 312 untreated slurry and in liquid phase slurry; and significant $\mathrm{N}_{2} \mathrm{O}$ emission only in the solid 313 fraction during the first 25 days of the storage period.

314 Our results showed that $\mathrm{CH}_{4}$ was not emitted from pig slurry until week 6 after the slurry 315 was removed from the storage pit. This delay in $\mathrm{CH}_{4}$ emission detected in the present study 316 has been observed in other studies (Moller et al., 2004; Sommer et al., 2007). The 317 equilibrium of methanogenic bacteria is generally achieved more slowly than the 318 equilibrium of the rest of bacterial populations that inhabit the slurry (Vavilin and 319 Angelidaki 2004). Additionally, Vavilin and Angelidaki (2004) also suggested that the slow 
320 growth of methanogenic bacteria may be related to the formation of specific bacterial 321 morphological aggregates or flocks. In the present study, aged slurry which could 322 presumably have already established methanogenic bacteria was used. This could have 323 accelerated the production of $\mathrm{CH}_{4}$. However, an important delay in the production of $\mathrm{CH}_{4}$ 324 was observed, probably due to the changes in slurry conditions from the pit under slatted 325 floor and the tanks, together with the vigorous mixing of the slurry at the beginning of the 326 study to promote homogenisation. These changes could have disrupted the anaerobic 327 conditions presumably already established under slatted floor and the structure of the 328 bacterial flocks, thus delaying the onset of methanogenic activity.

329 The understanding of the $\mathrm{CH}_{4}$ emission pattern during aged slurry storage is useful in order 330 to recommend a maximum period for outdoor storage to prevent significant losses of $\mathrm{CH}_{4}$, 331 applicable to Mediterranean conditions where aged pig slurry is stored generally without 332 covers during long periods. From our results, the recommended time of storage in summer 333 time in order to minimise $\mathrm{CH}_{4}$ losses from aged fattening pig slurry to the atmosphere 334 could be established between 30 to 35 days (week 4 to 5). This recommendation could be 335 applicable in those slurry management systems which consist on a pre-storage below slatted 336 floor during the whole fattening period followed by outdoor storage until its application to 337 agricultural land. This is specially the case in those areas where the use of livestock manure 338 as fertiliser is restricted to specific periods of the year (i.e. vulnerable areas under the 339 European Nitrates Directive, 91/676/EC), and therefore slurry is stored in outdoor storage 340 lagoons for long periods of time. Moreover, under the European Nitrates Directive storage 341 lagoons must have a minimum storage capacity of 3-4 months. During this time, and taking 342 into account the results obtained in the present study, major $\mathrm{CH}_{4}$ emissions to the 
343 atmosphere could be expected. According to our results, in storage periods longer than five

344 weeks, the use of gas collection systems in such storage installations to avoid $\mathrm{CH}_{4}$ losses

345 could be recommended. Although a wide range of management systems are used for pig

346 rearing and slurry handling worldwide, our results are valuable to characterise the evolution

347 of aged slurry, representative to a large extent of outdoor storage in Mediterranean areas

348 and in those cases where pre-storage under pits is expanded throughout the whole of the

349 fattening period and is not mixed with slurries from animals that are in other physiological

$350 \quad$ states.

351 The results obtained in this study concerning $\mathrm{C}-\mathrm{CH}_{4}\left(\mathrm{C}-\mathrm{CO}_{2}+\mathrm{C}-\mathrm{CH}_{4}\right)$ ratio show that, under

352 our experimental conditions, during the peak of $\mathrm{CH}_{4}$ emission, decomposition of $\mathrm{OM}$ was

353 dominated by methanogenic microbial community and thus, at this time, the biogas

354 produced could be used as energy source. However, the $\mathrm{C}-\mathrm{CH}_{4} /\left[\mathrm{C}-\mathrm{CO}_{2}+\mathrm{C}-\mathrm{CH}_{4}\right]$ ratio

355 during the peak of $\mathrm{CH}_{4}$ production obtained in the present study $(0.50-0.54)$ was lower

356 compared to other experiments. Sommer et al. (2007) obtained a ratio between $0.50-0.65$

357 during the $\mathrm{CH}_{4}$ production peak and Moller et al. (2004) obtained a ratio between 0.60 -

358 0.70. This difference could be attributable to the use of aged slurry in our study. Sommer et

359 al. (2007) and Moller et al. (2004) worked with fresh slurry, however the slurry used in this

360 work was obtained after 19 weeks of storage under the pit. The VS biodegradability in the

361 slurry after long pre-storage times is lower than that of the fresh slurry because the

362 degradable vs. non-degradable fraction increases with the age of the slurry (Sommer et al.

363 2004).

364 5. Conclusions 
365 From our results concerning 15-week storage period in summer conditions of two types of 366 aged fattening pig slurry: separated slurry (SS) and raw slurry (RS), we can conclude that:

- There is relevant transformation of the more degradable OM into soluble OM during the first weeks of aged fattening pig slurry storage. This transformation is more pronounced in the slurry with a higher initial OM concentration (RS) than in separated slurry (SS), indicating a higher hydrolytic, acidogenic and acetogenic activity, as well as higher rate of urea mineralisation and nitrogen denitrification rate at the beginning of the storage period in RS than in SS.

- In aged fattening pig slurry stored under Mediterranean summer conditions, the establishment of all bacterial groups involved in the anaerobic degradation process does not occur until week 5, shown in our results by the VFA accumulation and the negligible $\mathrm{CH}_{4}$ emission during the first five weeks of storage in both treatments.

- Slurry storage time and thus, the age of the slurry can decrease the biodegradability of $\mathrm{OM}$, since the non-degradable fraction of OM increases over storage time. Storage time can considerably affect the biodegradability of organic matter in pig slurry.

\section{Acknowledgements}

This work was supported by the Agrobiogás project financed by the Agroalimed Foundation of the Consellería de Agricultura, Pesca, Alimentación y Agua of Valencia, Spain. 
Amon B., Kryvoruchko V., Amon T., Zechmeister-Boltenstern S., 2006. Methane, nitrous oxide and ammonia emissions during storage and after application of dairy cattle slurry and 390 influence of slurry treatment. Agriculture, Ecosystems and Environment 112:153-162.

391 Angelidaki I., Ellegaard L., Ahring B.K., 1999. A comprehensive model of anaerobic 392 bioconversion of complex substrates to biogas. Biotechnol. Bioeng. 63 (3), 363-372.

393 APHA 2005. Standard Methods for the examination of water and wastewater. 21th Edn. 394 Greenberg A. E., Clesceri L. S., Eaton, A.D. (Eds.) American Public Health Association, 395 Washintong DC, USA.

396 Béline, F., Martinez J., Marol C., Guiraud G., 1998. Nitrogen transformations during 397 anaerobically stored ${ }^{15} \mathrm{~N}$-labelled pig slurry. Biores. Techn.64, 83-88.

398 Béline, F., Martinez J., Chadwick D., Guiziou F., Coste C.M., 1999. Factors affecting 399 nitrogen transformations and related nitrous oxide emissions from aerobically treated 400 piggery slurry. J Agric. Eng. Res, 73 (3): 235-243.

401 Cahn T.T., Verstegen M.W., Aarnink A.J., Schrama J.W., 1997. Influence of dietary factors 402 on nitrogen partitioninig and composition of urine and feces of fattening pigs. J. Anim. Sci. $403 \quad 75,700-706$.

404 Canh T.T., Sutton A.L., Aarnink M.W., Verstegen J.W., Schrama J.W., Bakker G.C., 1998. 405 Dietary carbohydrates alter the fecal composition and $\mathrm{pH}$ and the ammonia emission from 406 slurry of growing pigs. J. Anim. Sci. 76,1887-1895.

407 Cortus E.L., Lemay S.P., Barber E.M., Hill G.A., Godbout S., 2008. A dynamic model of 408 ammonia emission from urine puddles. Biosyst. Eng. 99, 390-402. 
409 Dinuccio E., Berg W., Balsari P., 2008. Gaseous emissions from the storage of untreated 410 slurries and the fractions obtained alter mechanical separation. Atmospheric Environment $411 \quad 42: 2448-2459$.

412 Fangueiro D., Coutinho J., Chadwick D., Moreira N., Trindade H., 2008. Effect of cattle 413 slurry separation on greenhouse gas and ammonia emissions during storage. J. Environ. 414 Qual. 37, 2322-2331.

415 Jouany J.P., 1982. Volatlile fatty acid and alcohol determination in digestive contents, 416 silage juices, bacterial cultures and anaerobic fermentor contents. Scienc. Alimen. 2(2), $417 \quad 131-144$.

418 Moller H.B., Sommer S.G., Ahring B.K., 2004. Biological degradation and greenhouse gas 419 emission during pre-storage of liquid animal manure. J. Environ. Qual. 33, 27-35.

420 Muck R.E., Steenhuis T.S., 1982. Nitrogen losses from manure storages. Agric. Wast. 4, $421 \quad 41-51$.

422 Nozhevnikova A.N., Rebak S., Kotsyurbenko O.R., Parshina S.N., Holliger C., Lettinga G., 423 2000. Anaerobic production and degradation of volatile fatty acids in low temperature 424 environments. Water Sci. Technol. 41(12), 39-46.

425 Panetta D.M., Powers W.J., Xin H., Kerr B.J., Stalder K.J., 2006. Nitrogen excretion and 426 ammonia emissions from pigs fed modified diets. J. Environ. Qual. 35, 1297-1308.

427 SAS. 2001. SAS User's Guide: Statics. Ver. 9.0. Cary, N.C.: SAS Institute Inc.

428 Sommer S.G., Husted S., 1995. A simple model of pH in slurry. J. Agricul. Sc. 124, 447429453. 
430 Sommer,S. G., Moller H. B., 2002. Reduction in methane and nitrous oxide emission from 431 animal slurry through anaerobic digestion. Non-CO2 Greenhouse Gases, Van Ham, Baede, 432 Guicherit and Williams- Jacobse (Eds.) Millpress, Rotterdam, pp. 475-479.

433 Sommer S.G., Petersen S.O., Moller H.B., 2004. Algorithms for calculating methane and 434 nitrous oxide emissions from manure management. Nut. Cycl. Agroecosys. 69, 143-154.

435 Sommer S.G., Petersen S.O., Sorensen P., Poulsen H.D., Moller H.B. 2007. Methane and 436 carbon dioxide emissions and nitrogen turnover during liquid manure storage. Nut. Cycl. 437 Agroecosys. 78, 27-36.

438 Vavilin V.A., Rytov S.V., Lokshina L.Y., 1996. A description of hydrolysis kinetics in 439 anaerobic degradation of particulate organic matter. Biores. Techn. 56 (2/3), 229-237.

440 Vavilin V.A., Angelidaki I., 2004. Anaerobic degradation of solid material: Importance of 441 initiation centers for methanogenesis, mixing intensity, and 2D distributed model. 442 Biotechn. Bioen. 89 (1), 113-122.

443 Van Soest P. J., 1991. Methods for dietary fiber, neutral detergent fiber, and nonstarch 444 polysaccharides in relation to animal nutrition. J. Dairy Sci. 74(10), 3583-3597.

445 Zhu J., Ndegwa P.M., Luo A., 2000. Changes in swine manure solids during storage may 446 affect separation efficiency. Appl. Engin. Agricul. 16 (5), 571-575. 
448 Fig. 1. Evolution of the hourly environmental ( $\mathrm{T}^{\mathrm{o}}$ ambient: dotted line) and slurry

449 ( $\mathrm{T}^{\mathrm{o}}$ slurry: continuous line) temperature.

450

451 Fig. 2. Evolution of the total solids (TS: dotted line) and volatile solids (VS:

452 continuous line) of the separated $(\boldsymbol{\Delta})$ and raw slurry $(\times)$. Error bars indicate

453 standard error $(n=3)$. The statistical differences between treatments are marked as

454 follows: $* * * \mathrm{p}<0.001,{ }^{* *} \mathrm{p}<0.01$ and $* \mathrm{p}<0.05$

455

456 Fig. 3. Evolution of the dissolved chemical oxygen demand $\left(\mathrm{COD}_{\mathrm{d}}\right)$ of the

457 separated (continuous line and $\mathbf{\Delta}$ ) and raw slurry (dotted line and $\times$ ). Error bars

458 indicate standard error $(n=3)$. The statistical differences between treatments are

459

marked as follows: $* * * \mathrm{p}<0.001, * * \mathrm{p}<0.01$ and $* \mathrm{p}<0.05$

460

461 Fig. 4. Evolution of the total volatile fatty acids (VFA) content and the profile of VFA

462 concentration during the storage time of the separated (continuous line and $\mathbf{\Delta}$ ) and raw

463 slurry (dotted line and $\times$ ). Error bars indicate standard error (observation $=3$ ). The statistical

464 differences between treatments are marked as follow: $* * * \mathrm{p}<0.001, * * \mathrm{p}<0.01$ and $* \mathrm{p}$

$465<0.05$.

466

467 Fig. 5. Evolution of the $\mathrm{pH}$ of the separated (continuous line and $\mathbf{\Delta}$ ) and raw slurry (dotted

468 line and $\times$ ). Error bars indicate standard error $(n=3)$. The statistical differences between

469 treatments are marked as follow: $* * * p<0.001, * * p<0.01$ and $* \mathrm{p}<0.05$. 
471 Fig. 6. Emissions of $\mathrm{CO}_{2}$, and $\mathrm{NH}_{3}$ from separated (continuous line and $\mathbf{\Delta}$ ) and raw slurry 472 (dotted line and $\times$ ). All registrations are average from 12 observations from three vessels, 473 error bars indicate standard error. The statistical differences between treatments are marked 474 as follow: $* * * \mathrm{p}<0.001, * * \mathrm{p}<0.01$ and $* \mathrm{p}<0.05$. Missing data on week 11 are due to 475 equipment malfunction.

476

477 Fig. 7. Emissions of $\mathrm{CH}_{4}$ from separated (continuous line and $\mathbf{\Delta}$ ) and raw slurry (dotted line 478 and $\times$ ). All registrations are average from 12 observations from three vessels, error bars 479 indicate standard error. The statistical differences between treatments are marked as follow: $480 * * * \mathrm{p}<0.001, * * \mathrm{p}<0.01$ and $* \mathrm{p}<0.05$. Missing data on week 11 are due to equip 481 malfunction.

482 483 484 485 
Table 1. Chemical manure composition from separated and raw aged fattening pig slurries in outdoor storage conditions at different storage times in high temperature conditions.

\begin{tabular}{|c|c|c|c|c|}
\hline Storage time (weeks) & & 0 & 9 & 15 \\
\hline & Separated Slurry & 3.5 & 3.2 & 2.9 \\
\hline Total Kjeldhal Nitrogen & Raw Slurry & 4.1 & 3.6 & 3.5 \\
\hline \multirow{3}{*}{$\mathrm{g} \mathrm{kg}^{-1}[\mathrm{FM}]$} & SEM & 0.23 & 0.23 & 0.23 \\
\hline & Significance & $\mathrm{ns}$ & $\mathrm{ns}$ & $\mathrm{p}<0.05$ \\
\hline & Separated Slurry & 2.6 & 2.5 & 2.2 \\
\hline Dissolved Kjeldhal Nitrogen & Raw Slurry & 3.1 & 2.8 & 2.6 \\
\hline \multirow[t]{3}{*}{$\mathrm{g} \mathrm{kg}^{-1}[\mathrm{FM}]$} & SEM & 0.18 & 0.18 & 0.18 \\
\hline & Significance & $\mathrm{ns}$ & $\mathrm{ns}$ & $\mathrm{ns}$ \\
\hline & Separated Slurry & 4.23 & 2.22 & 4.12 \\
\hline Neutral Detergent Fibre & Raw Slurry & 6.34 & 5.31 & 10.6 \\
\hline \multirow[t]{3}{*}{$\mathrm{g} \mathrm{kg}^{-1}[\mathrm{FM}]$} & SEM & 0.761 & 0.761 & 0.761 \\
\hline & Significance & $\mathrm{ns}$ & $\mathrm{p}<0.05$ & $\mathrm{p}<0.001$ \\
\hline & Separated Slurry & 1.50 & 0.754 & 1.62 \\
\hline Acid Detergent Fiber & Raw Slurry & 2.44 & 2.12 & 4.52 \\
\hline \multirow[t]{3}{*}{$\mathrm{g} \mathrm{kg}^{-1}[\mathrm{FM}]$} & SEM & 0.314 & 0.314 & 0.314 \\
\hline & Significance & ns & $\mathrm{p}<0.05$ & $\mathrm{p}<0.001$ \\
\hline & Separated Slurry & 0.60 & 0.32 & 1.76 \\
\hline Acid Detergent Lignin & Raw Slurry & 0.83 & 0.78 & 3.3 \\
\hline \multirow[t]{2}{*}{$\mathrm{g} \mathrm{kg}^{-1}[\mathrm{FM}]$} & SEM & 0.153 & 0.153 & 0.153 \\
\hline & Significance & ns & ns & $\mathrm{p}<0.001$ \\
\hline
\end{tabular}




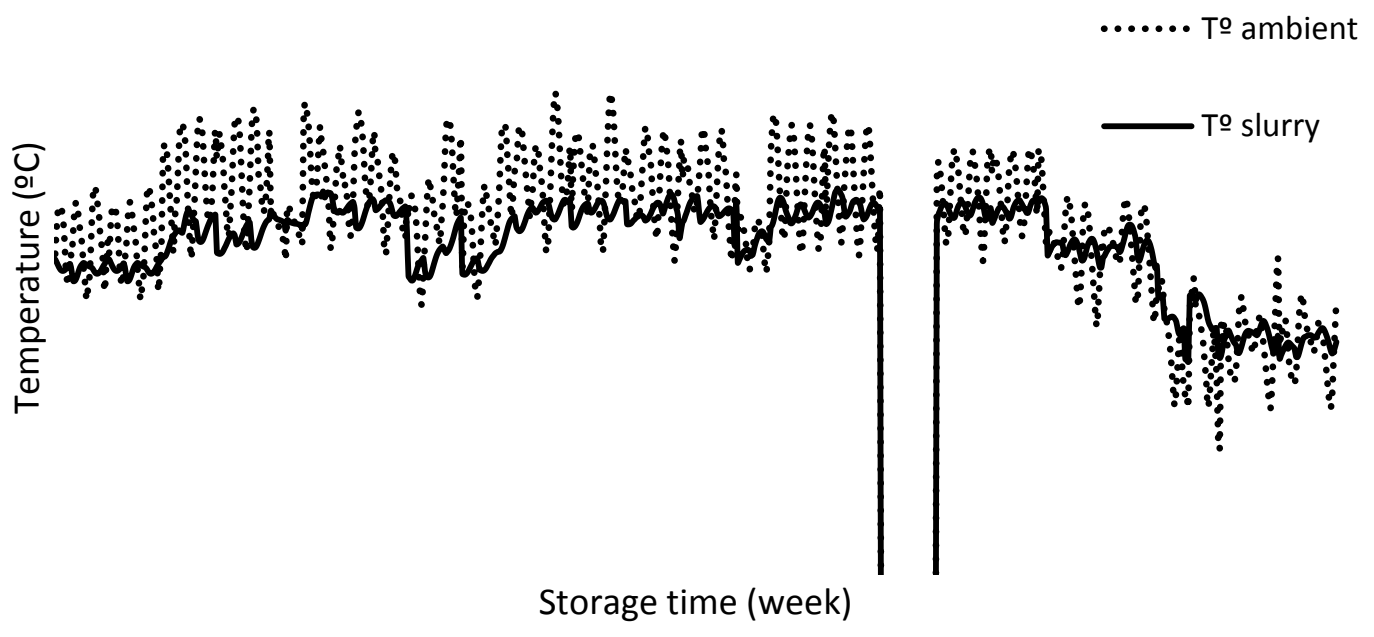

493

494 Fig. 1. Evolution of the hourly environmental ( $\mathrm{T}^{\mathrm{o}}$ ambient: dotted line) and slurry

495

( $\mathrm{T}^{\mathrm{o}}$ slurry: continuous line) temperature.

496

497

498 


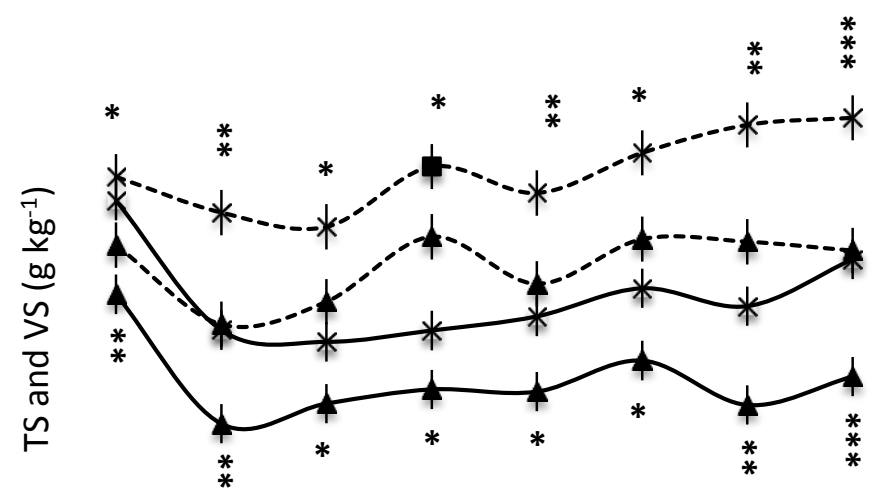

502

503

504

505

506

507

508
Fig. 2. Evolution of the total solids (TS: dotted line) and volatile solids (VS: continuous line) of the separated $(\boldsymbol{\Delta})$ and raw aged fattening pig slurry $(\times)$. Error bars indicate standard error $(n=3)$. The statistical differences between treatments are marked as follows: $* * * p<0.001$,

$$
* * \mathrm{p}<0.01 \text { and } * \mathrm{p}<0.05
$$




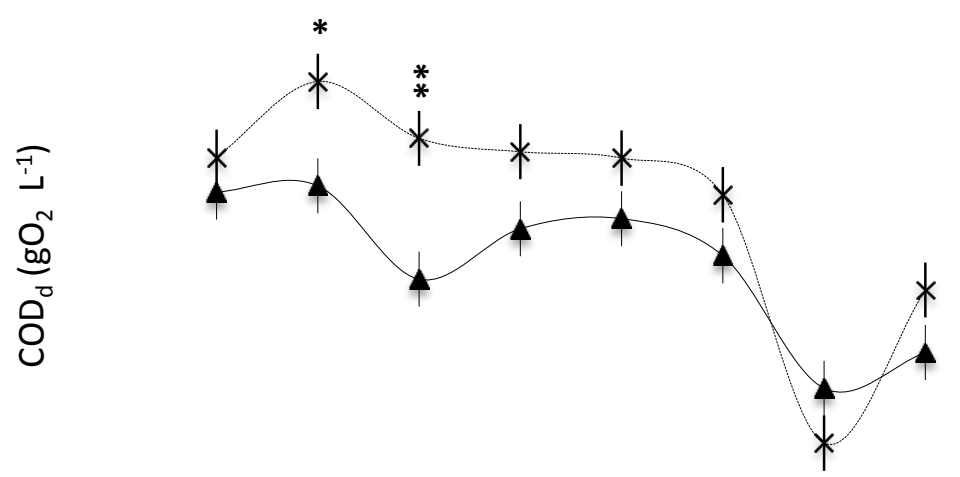

Storage time (week)

511

512

513

514

515

516

517

518

519
Fig. 3. Evolution of the dissolved chemical oxygen demand $\left(\mathrm{COD}_{\mathrm{d}}\right)$ of the separated (continuous line and $\left.\mathbf{\Delta}\right)$ and raw aged fattening pig slurry (dotted line and $\times$ ). Error bars indicate standard error $(\mathrm{n}=3)$. The statistical differences between treatments are marked as follows: ${ }^{* * *} \mathrm{p}<0.001,{ }^{* *} \mathrm{p}<0.01$ and $* \mathrm{p}$ $<0.05$ 


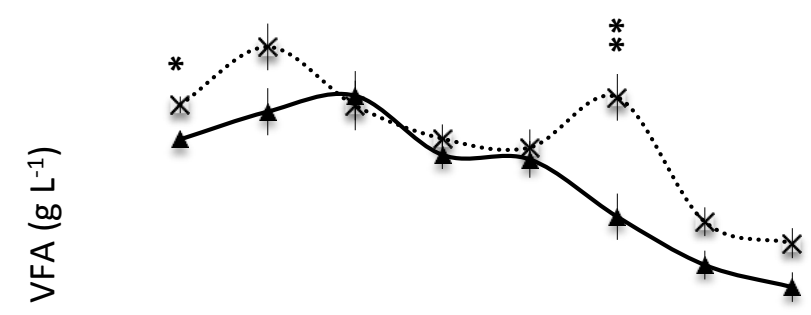

storage time (week)

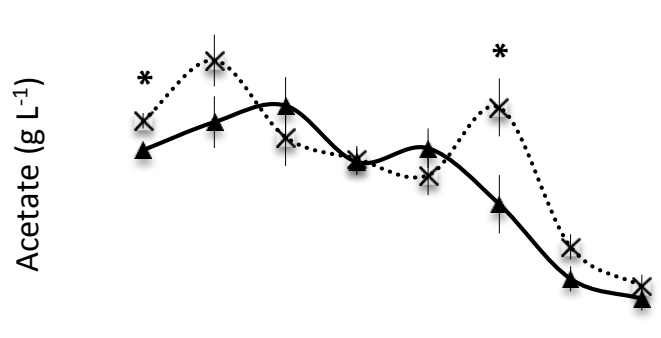

storage time (week)

521

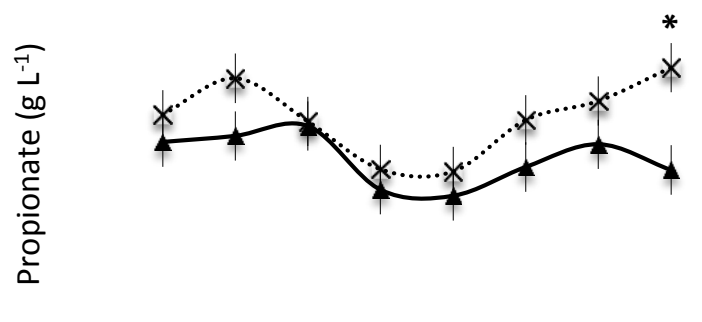

storage time (week)

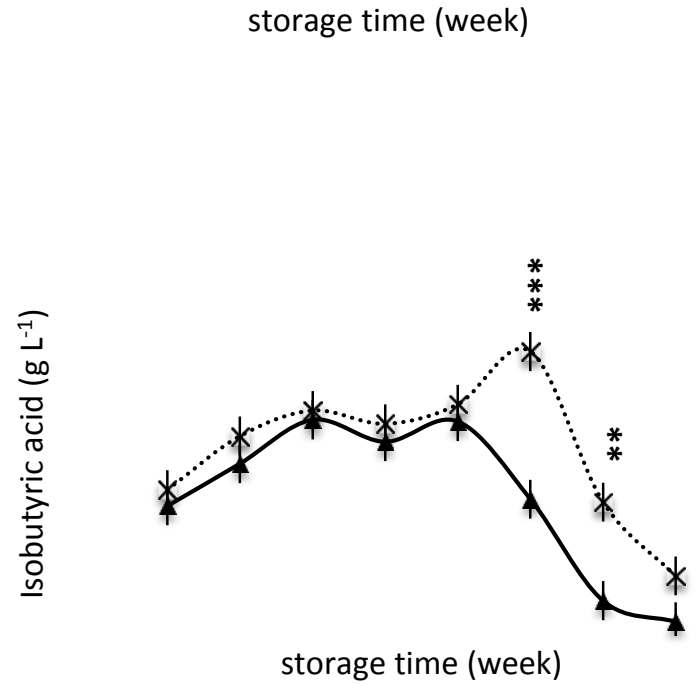

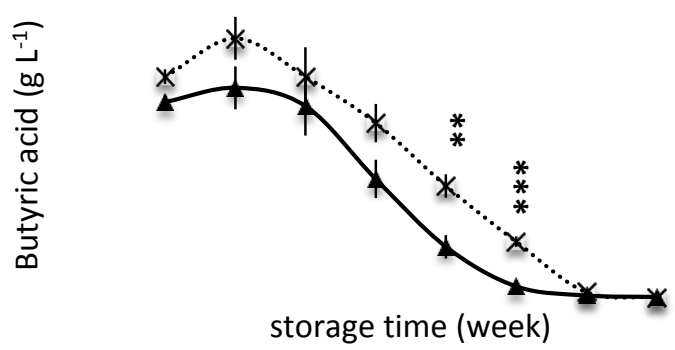

Fig. 4. Evolution of the total volatile fatty acids (VFA) content and the profile of VFA concentration during the storage time of the separated (continuous line and $\mathbf{\Delta}$ ) and raw aged fattening pig slurry (dotted line and $\times$ ). Error bars indicate standard error (observation $=3$ ). The statistical differences between treatments are marked as follow: 


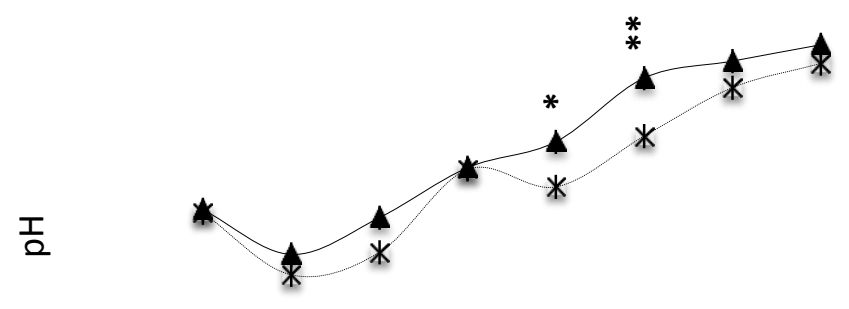

528

storage time (week)

529

530

531

532

533

534

535
Fig. 5. Evolution of the $\mathrm{pH}$ of the separated (continuous line and $\boldsymbol{\Delta}$ ) and raw aged fattening pig slurry (dotted line and $\times$ ). Error bars indicate standard error (observation $=3$ ). The statistical differences between treatments are marked as follow: $* * * \mathrm{p}<0.001, * * \mathrm{p}<0.01$ and $* \mathrm{p}<0.05$. 
538

539

540

541

542

543

544

545

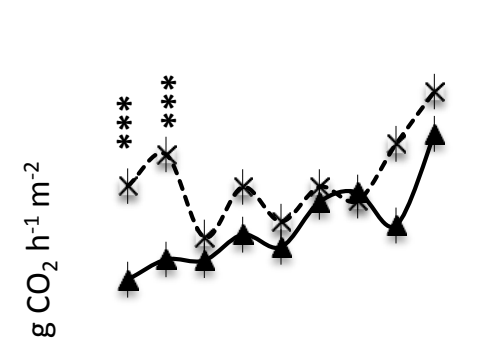

storage time (week)

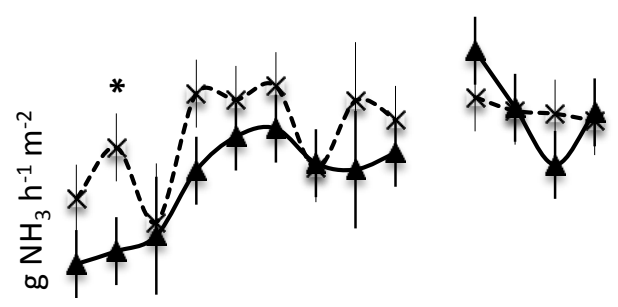

storage time (week)

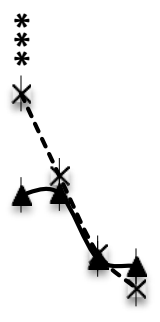

Fig. 6. Emissions of $\mathrm{CO}_{2}$, and $\mathrm{NH}_{3}$ from separated (continuous line and $\mathbf{\Delta}$ ) and raw aged fattening pig slurry (dotted line and $\times$ ). All registrations are average from 12 observations from three vessels, error bars indicate standard error. The statistical differences between treatments are marked as follow: $* * * p<0.001, * * p<0.01$ and $* \mathrm{p}<0.05$. Missing data on week 11 are due to equipment malfunction. 


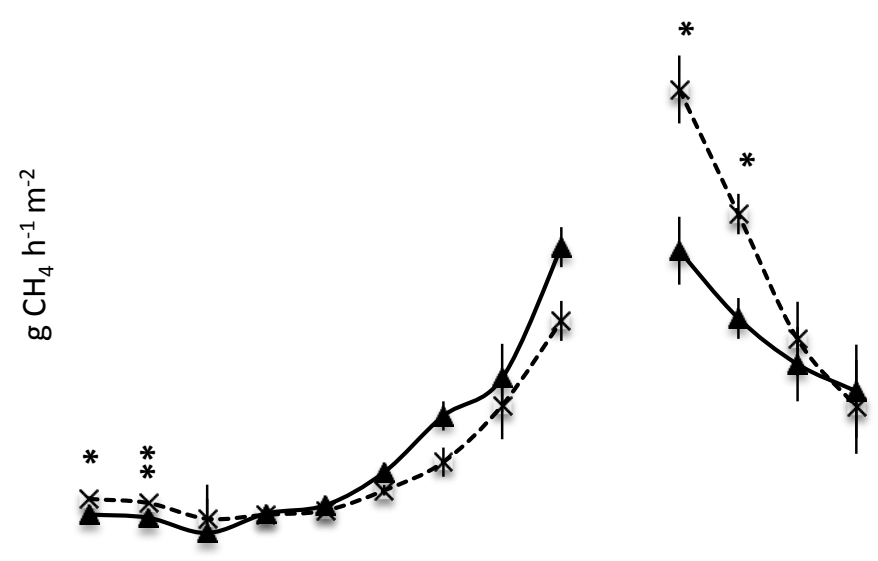

storage time (week)

548 Fig. 7. Emissions of $\mathrm{CH}_{4}$ from separated (continuous line and $\boldsymbol{\Delta}$ ) and raw aged fattening 549 pig slurry (dotted line and $\times$ ). All registrations are average from 12 observations from three 550 vessels, error bars indicate standard error. The statistical differences between treatments are 551 marked as follow: $* * * \mathrm{p}<0.001, * * \mathrm{p}<0.01$ and $* \mathrm{p}<0.05$. Missing data on week 11 are due to 552 equipment malfunction. 